InOedia $\quad \begin{aligned} & \text { InMedia } \\ & \text { The French Journal of Media Studies }\end{aligned}$

$6 \mid 2017$

Fields of Dreams and Messages

Laura Horak, Girls Will Be Boys: Cross-Dressed Women, Lesbians, and American Cinema

New Brunswick: Rutgers University Press, 2016, 256 pages

Anne Crémieux

(2) OpenEdition

Journals

Electronic version

URL: http://journals.openedition.org/inmedia/889

DOI: 10.4000/inmedia.889

ISSN: 2259-4728

Publisher

Center for Research on the English-Speaking World (CREW)

Electronic reference

Anne Crémieux, « Laura Horak, Girls Will Be Boys: Cross-Dressed Women, Lesbians, and American Cinema », InMedia [Online], 6 | 2017, Online since 01 July 2017, connection on 23 September 2020. URL:

http://journals.openedition.org/inmedia/889; DOI : https://doi.org/10.4000/inmedia.889

This text was automatically generated on 23 September 2020 .

(c) InMedia 


\title{
Laura Horak, Girls Will Be Boys: Cross- Dressed Women, Lesbians, and American Cinema
}

New Brunswick: Rutgers University Press, 2016, 256 pages

\author{
Anne Crémieux
}

\section{REFERENCES}

Laura Horak, Girls Will Be Boys: Cross-Dressed Women, Lesbians, and American Cinema, New Brunswick: Rutgers University Press, 2016, 256 pages

1 Marlene Dietrich's top hat, Greta Garbo's deep voice or Katharine Hepburn's determined gait are all world-famous representations of women in the American cinema of the 20s and 30s. They were superstars who, both on and off the screen, seemed to live outside the world of patriarchy that ruled other women's lives. There was a sense of sophisticated mystery about their sexuality that has since been lifted but which Laura Horak approaches for what they might have signified at the time, couching her argument in the study of dozens of examples of masculine women in celluloid films and other media.

A simple and compelling limitation of the range of Horak's study to female characters wearing pants in fiction films from the beginning of cinema to 1934 enables her to draw convincing conclusions about how female masculinity on screen evolved both in terms of visibility and meaning.

In the introduction, Horak debunks a number of myths about women wearing masculine clothing in early cinema, namely that they are "transgressive," that they "challenge patriarchy and the gender binary," that they are "the only way movies could represent lesbianism" at the time and that they were very rare (1-2). In fact, cross-dressed women in films prior to 1940 and particularly prior to 1915 were not rare, as the 18-page appendix demonstrates. And they did not necessarily signify 
lesbianism, which was largely condemned, but on the contrary may have functioned to "help the medium become more respectable" (2), at least until the late 1920s. Horak positions herself against writers she otherwise lauds for their groundbreaking work, notably Andrea Weiss (Vampires and Violets) and Vito Russo (The Celluloid Closet), because she refuses to "read historical representations in the light of today's codes and identities, instrumentalize gender nonconformity as a sign of homosexuality, and construct a progressive, continuous trajectory from the 'bad old times' to the enlightened present." She feels they "miss the opportunity to be truly surprised by a past radically different from the present, a past that might prompt us to imagine a radically different future" (3). Whether these accusations are entirely founded may be subject to debate, but Horak's standpoint certainly marks a new approach to gender studies that is liberated from past needs to prove that no matter how repressed, homosexuality has always been present and can still be detected in past cultural productions. Horak does not feel the need to assert something that is no more denied. She hardly needs to disclose and provide proof of the sexuality of the actresses, for instance, as the secrets have been lifted. Her introduction asserts that "The specter of sexual inversion did not haunt the cross-dressed women of cinema's first decades" (6) and that it should therefore not be misconstrued. Frontier's women, in particular, often wore pants because it simply seemed to fit the job description, as many who championed exercise and outdoors activities for women argued that "traditional women's clothing was contributing to the nation's sickliness" (9). The introduction establishes three waves of crossed-dressed women in cinema - 1908-1921, when crossdressing by women generally signified sophistication within a media seeking recognition; 1922-1928, when the establishment of the star system assigned certain looks to certain actresses and limited cross-dressing to a few stars; and 1929-1934 when the Hays code was being drawn and the taboo of homosexuality was coming under target.

The book is divided in two parts of two chapters each, separated by a one-chapter Intermezzo.

5 Part I focuses on the first wave and the many tomboy parts, soon to be taken over by boy stars such as Jackie Coogan. Part II deals with the second and third wave, "when wholesome meanings vied with more transgressive ones" (12), with clear references to lesbianism in A Florida Enchantment (1914), moving on to a period when reviewers in particular "began to use cross-dressing as a euphemism for lesbianism" (16).

6 Part I is about films up to 1921. The first chapter is a study of the "Female Boy" of the early years, as actresses held quantities of boyish roles in the 1910s. According to Horak's detailed research, this was first a ploy to "uplift" cinema as a respectable art form, that was later perceived as a remnant of theatre practices ill-suited to the immersive media that cinema was meant to be. At the same time, young soldiers were coming back from a victorious war and "femininity was no longer a valued characteristic of boyhood" (53).

7 The second chapter is entitled "Cowboy Girls, Girl Spies, and the Homoerotic Frontier." The lifestyle of the frontier is presented as requiring practical dress for women that include pants, in territories were women are scarce and quickly gain the right to vote (most Western states included the woman's vote in their constitution in the late $19^{\text {th }}$ century). They "affirm a virile national ideal" (56), including against feminized racial others (Mexicans, Native Americans), showing "how important ostensibly deviant 
expressions of gender and sexuality were to the construction of normative, national ideals" (60). Horak looks at the specific gender dynamics of the West, where women of ill-repute dominated an unbalanced population and where most men were considered unfit for the company of respectable women. It is therefore logical that heterosexual romance, to seem realistic, should be complicated by cross-dressing that allows at first for a male friendship, the most common form of affective bond in the West, to turn into romance once the gender of the cross-dresser is revealed. The homoerotic implications, undeniable today as in the past, may therefore not be the only or primary grid of interpretation to apply to these films.

8 The third chapter, or Intermezzo, focuses on the various representations of the comedic play A Florida Enchantment, first staged on Broadway in 1896 and adapted 18 years later by Vitagraph for the moving pictures. Except for one New York critic, the film was received as a "good, wholesome comedy" that families will enjoy, while the play was largely criticized for showcasing sexual and gender perversion. Horak goes to great lengths to interpret this difference, from one media to another, from one generation to the next. Most importantly, the film seems to have been received in what was still an age of innocence as far as gender-bending was concerned, to be contrasted with the rising controversies to come and the fast-diminishing number of female crossdressing in films as the industry was becoming more organized.

Part II focuses on "The Emergence of Lesbian Visibility" from 1921 to 1934, a period in which mainstream knowledge about lesbianism widens, both giving new meaning to female cross-dressing in film and making it more vulnerable to censorship.

Chapter 4 is entitled "Enter the Lesbian: Cosmopolitanism, Trousers, and Lesbians in the 1920s." In the late 1920s, The Captive (1926) was followed by the publishing and strong censorship of Radclyffe Hall's largely auto-biographical The Well of Loneliness (1928), in a decade marked by relative sexual freedom and gender-breaking fashion. Horak interprets lesbian cameos in Four Horsemen of the Apocalypse (1921) or Manslaughter (1922) not so much as groundbreaking instances of lesbians on screen but rather as signs of the times, when narrative realism required including such characters in the background. It seemed like the time had come, and Radclyffe Hall's book The Well of Loneliness became enough of a cultural icon for it to make a comedic cameo in The Secret Witness (1931) (167). The author draws several visual parallels between famous portraits of masculine lesbians such as Radclyffe Hall or Jane Heap and photograms from What's the World Coming To $(1926)$ or Wings $(1927)(135,156)$, in an effort to map how these images may have been perceived at the time. She quotes reviewers but also questions their motivations in using certain vocabulary or their opinion about what "sophisticated" audiences might understand as opposed to the rest of the population. The discourse on female masculinity evolved over the years and Horak is exemplary in discussing the slight changes and variations within the context of Mae West plays and the Roscoe "Fatty" Arbuckle scandal, when the only woman accepted in the director's guild is the suit-wearing Dorothy Arzner.

11 The book's last chapter, "The Lesbian Vogue and the Backlash Against Cross-Dressed Women in the 1930s," concludes on both a high and low note, with the now cult 1930s films of Garbo, Dietrich and Hepburn, which were both impressively daring and contributed to the strict application of the 1934 code of self-censorship. Horak describes how Garbo, Dietrich and playwright Mercedes de Acosta recurrently made the news in ways that made their sexuality a thinly-kept secret. Some of the most 
famous moments and lines of their films, such as Dietrich's outfit in Morocco or Garbo's "bachelor" comment in Queen Christina, were reprised by the stars in interviews or at public events. The context of masculine outfits for women is discussed at length, in an attempt to truly decipher what the images might have meant to audiences at the time. Images of women in male garb but also of women kissing on the mouth, in both Morocco (1931) and Queen Christina (1933), and in the highly controversial German film Mädchen in Uniforms (1931). They must have been more ambiguous at the time than they seem today for the scenes to make it past the cutting-room floor. The chapter concludes on Sylvia Scarlett (1935, made in 1934) and its bouts with censorship, producing a genderbending comedy carried by Hepburn's mesmerizing performance of masculinity (222). With this fascinatingly detailed and thorough study of cross-dressed women in precode cinema, Horak puts the light on a seldom studied practice that has few connections with its male counterpart, as crossed-dressed men spring from such a separate tradition and have been received widely differently. The fact that women wearing pants do not constitute a form of cross-dressing anymore is a sign of how ideologically complex the practice must have been in a not-so-distant past.

\section{AUTHORS}

\section{ANNE CRÉMIEUX}

Université Paris Ouest - Nanterre 